\title{
ESTHER BARBARA CHALMERS'S SCOTTISH INTERNATIONAL LIVES
}

\author{
Kali Israel, University of Michigan
}

It is a truism that lives can be told in many ways.

Some ways ratify or expand existing or emerging paths of scholarship. Some bring surprises, including surprises which turn out to have been in plain view.

The Scottish international lives in this essay will include but not be limited to that of Esther Chalmers herself.

\section{I.}

Here is one way one could tell the life of Esther Barbara Chalmers, (1894-1983). This way connects with some broad themes in women's history, especially histories of women's transnational activism in the twentieth century; women, war, and anti-war activism; women in socialist and other international organizations; and the history of women's passionate relationships. These are fields with deep backgrounds which continue to expand. ${ }^{1}$

\footnotetext{
1 The bibliography on women and international organizations is very rich. See, e.g., Jill Liddington, The Long Road to Greenham: Feminism and Anti-Militarism in Britain Since 1820 (London: Virago, 1990) and Sybil Oldfield, Women Humanitarians: A Biographical Dictionary of British Women Active between 1900 and 1950: "Doers of the World" (London: Continuum, 2001); for more recent work, see Women's History Review 26:2 (2017), special issue on "Women's International Activism During the Interwar Period, 1919-1939," especially Ingrid Sharp \& Matthew Stibbe, "Women's International Activism During the Inter-War
} 
Although she began university studies in Edinburgh in 1915 under pressure from her mother, Chalmers was attracted by the possibility of war work, as was her older sister Alison Bell Chalmers (later Volchaneski). ${ }^{2}$ Alison Bell Chalmers

period, 1919-1939": 163-172, and the later volume from the same project, Ingrid Sharp \& Matthew Stibbe, eds., Women Activists Between War and Peace: Europe, 1918-1923 (London: Bloomsbury, 2017); see also Leila Rupp, Worlds of Women: The Making of an International Women's Movement (Princeton: Princeton University Press, 1997).

${ }^{2}$ Unpublished Autobiography, Esther Barbara Chalmers, National Library of Scotland (hereafter NLS), Acc. 8695/1, ch. 4, pp. 4-5 (hereafter NLS and hereafter cited as EBC autobiography). Note: This document has separate and repeating pagination for chapters and sometimes for sections which begin anew without a new chapter number, often separated by a brightly colored divider page. I will be as clear as possible in specifying page locations, including using "p." or "pp." as above, which I will omit for other cited works. This text also may end sooner than planned; see NLS Acc. $8695 / 16$ for an outline of EBC's plan for the work. The NLS inventory, available online at https://www.nls.uk/catalogues/online/cnmi/inventories/acc86 95.pdf (accessed 10/17/2017) is invaluable and I have used its headings, as well as numeration, in some notes to identify folders. I regret that neither NLS records nor staff memories could tell me who did the inventory and organization of the archive. Alison Bell Chalmers Volchaneski or Voltancheski (sometimes also spelled Voltchanecki or Volcanecki), b. 1884 (see passport, NLS Acc. 8695/114), d. 1959 in Anstruther (NLS Acc. 8696/107; see also "Out of the Green Box"-see below n. 84 (hereafter "Green Box"), handwritten note by $\mathrm{EBC}$ on 255). Alison was known as "Elsie" in the family and 
became a probationer nurse in a French hospital before ultimately joining the Scottish Women's Hospitals units in 1916. ${ }^{3}$ Esther, however, after attempting Red Cross training, found it impossible to deal with blood; she instead took an Edinburgh University course in pathology and bacteriology in order to work as a laboratory technician along with her friend Ada Fyfe, whom she knew as a fellow-member of the Ladies' Caledonian Club. ${ }^{4}$ Frustrated by the difficulty of getting work despite "bombarding Labour exchanges, interviewing Red Cross Commandants, filing applications to join the Scottish Women's Hospitals for Foreign Service, even advertising in the Scotsman," Esther Chalmers became involved in the processing of sphagnum moss for medical use in Edinburghof which she left a fascinating account. Finally, she and Ada Fyfe got work as lab technicians at the Royal Victoria Military Hospital at Netley near Southampton. ${ }^{5}$ She was seconded for some time to supervising the "recycling" of dud bombs in order

is named thus in some of EBC's papers; she is abbreviated as ABV in the NLS inventory of EBC's papers.

${ }^{3}$ EBC autobiography, NLS Acc. 8695/1, ch. 5, p. 9, says Alison joined the Scottish Women's Hospital in July 1916; Alison is noted in the entry for EBC in the inventory of personnel at http://scottishwomenshospitals.co.uk/women/ (accessed 10/16/2017) but does not have an entry herself.

${ }^{4}$ EBC autobiography, NLS Acc. 8695/1, ch. 5, p. 2. On the Ladies' Caledonian Club, see Elspeth J. Boog Watson, "The Ladies' Caledonian Club, 1908-1970," tss. in NLS, shelfmark HP3.84.728; this is a pamphlet dated by the library "1970s?" accompanied by a second pamphlet by Elizabeth D.

Stevenson covering the years 1970-82; the club closed in 1981. As the Club was only founded in 1908, EBC and Fyve were relatively early members, amongst whom the most prominent was Elsie Inglis (Boog Watson, 2).

${ }^{5}$ EBC autobiography, NLS Acc. 8695/1, ch. 5, p. 3. 
to retrieve their powder at a factory near the hospital; her autobiography notes her worry about possible assault by a male worker who harassed her and lack of respect from a male manager who took credit for her work. ${ }^{6}$ After the war, eager for further work ("out of work once more I must find another war métier") she was also desperate to return to Europe, to which she had passionately committed before the war. She found through "a sister of one of Alison's Scottish Women's friends" that the Friends' War Victims' Relief Committee in France was in need of workers with strong French language skills. $^{7}$

Through this work, initially in Lisieux in 1918 and then in the Marne, working with refugees and people returning from wartime displacement, Esther Chalmers embarked on a career in France and Belgium. Through the Friends, she became close to a cluster of women, including several Americans like Eleanor Lansing Dulles, Margaret Scattergood, and Mary Kelsey. ${ }^{8}$ In a circle replete with nicknames and shared jokes (Esther was "Jock"), lasting friendships and partnerships were formed. ${ }^{9}$ Esther Chalmers returned to Edinburgh in 1920/21 to impatiently finish her degree-whilst frustratedly remarking on "bitter unemployment, inadequate relief"; she bearded a Bishop to demand that the Churches act more strongly. She returned to France in 1922 at the invitation of Mary Kelsey. ${ }^{10}$

${ }^{6}$ EBC autobiography, NLS Acc. 8695/1, ch. 5, pp. 17-22.

${ }^{7}$ EBC autobiography, NLS Acc. 8695/1, ch. 5, pp. 24.

${ }^{8}$ EBC autobiography, NLS Acc. 8695/1, especially section marked "The Marne - 1919" which appears to have been annotated by Scattergood and intended for separate publication.

${ }^{9}$ EBC autobiography, NLS Acc. 8695/1, “The Marne1919," p. 4.

${ }^{10}$ EBC autobiography, NLS Acc. 8695/1, section marked simply “9," pp. 2-3, and ch. 10, 1. Mary Kelsey is somewhat 
Kelsey wanted to start "“an international school for the discussion of world affairs," a project which led to the Honfleur Conferences to promote peace between nations. ${ }^{11}$ During this work with Kelsey, Esther Chalmers met "Mesdemoiselles Pognon," feminists to whom she paid tribute in her memoir; Maria and her daughter Matilde Pognon were early members of Le Droit Humain, an international cross-gender masonic

elusive, but she was clearly a pacifist and feminist activist from the USA; see

http://www.swarthmore.edu/Library/friends/Peace\%20in\%20 Friends/PeaceTest\%20_\%20K_O.htm (accessed 10/16/2017); https://www.findagrave.com/cgibin/fg.cgi?page $=$ gr\&GRid=161228552 $($ accessed 10/16/2017); Mary Kelsey, "Love Thy Neighbour," The Messenger of Peace, 45-46 (1920): 8-12, is an essay by Kelsey dated December 1919 from Short Hills, NJ. EBC claims that Kelsey was not a Quaker although close to them, and EBC notes "something magnetic about Mary's personality, something inherited from the great-grandmother she liked to claim - a Scotch woman burnt as a witch!" and cryptically alludes to her papers being "buried deep in the subterranean vaults of the Rockefeller Center"; EBC autobiography, NLS Acc. 8695/1, ch. 11, p. 10, 15. See also NLS Acc. 8695/5, "Draft and copy description of EBC s return to Honfleur, Normandy, with Mary Kelsey in 1946...”. ${ }^{11}$ EBC autobiography, NLS Acc. 8695/1, ch. 10, p. 1; for more on Kelsey's project, see ibid., pp. 2-3, and ch. 11, on the 1923 conference; Isabelle Vahe, "Entre ombres et lumières, le parcours singulier d'une féministe pacifiste, Jeanne Mélin (1877-1964)," Clio: Histoire, femmes et sociétés 24 (2006): 231-250; online edition, 6; http://clio.revues.org/4502, accessed 10/17/2017; and Martin Ceadel, Living the Great Illusion: Sir Norman Angell, 1872-1967 (Oxford: OUP, 2009), 260. 
organization "aimed at the education and emancipation of women," which Chalmers joined. ${ }^{12}$ Fatefully, Kelsey's project led to Esther Chalmers's first meeting with Lucie Dejardin. ${ }^{13}$

Dejardin, born in 1875, was a Belgian working-class socialist feminist trade unionist, heroic member of the resistance during World War I, child welfare organizer, and peace activist; she was a Belgian delegate to the 1921 Vienna conference of the Women's International League for Peace and Freedom; she was the first woman member elected to the Belgian Chamber of Representatives. ${ }^{14}$ After some diversions,

${ }^{12}$ EBC may have confused the relationship of the Pognons by the time she was writing; she probably met Maria Pognon and her daughter, Mathilde. EBC autobiography, NLS Acc. $8695 / 1$, ch. 11, p. 10: "To harbor such pioneering ideas was genuinely dangerous, hence the sacred oaths that each member had to swear never to reveal the identity of his or her fellow-I had almost written: conspirators. And that indeed was how these early Free Masons were popularly regarded. The courage shown by the women in France and Belgium who dared to join 'Le Droit Humain' cannot be overestimated." See also NLS Acc. 8695/62, 63, 64, 189, 286, 290, 299, 331. On Le Droit Humain, see https://droithumain.org/web/?lang=en (accessed 10/22/2017); there is an Histoire de la Federation belge du droit humain, 3 vols. (Brussels: Editions du Droit Humain, 1982-84) which I have not been able to consult. A peculiar certificate inducting EBC into "the Order of the Ancient Wisdom," during her war work near Southampton, in December 1916, is in memorandum book, NLS Acc. 8795/52.

${ }^{13}$ EBC autobiography, NLS Acc. 8695/1, ch. 10, pp. 5-7.

${ }^{14}$ On Dejardin, see

http://connaitrelawallonie.wallonie.be/fr/wallonsmarquants/dictionnaire/dejardin-lucie\#.WeYWQUzMzX8, accessed 10/17/2017; and E. B. Chalmers, Lucie Dejardin: 
including visiting her sister Alison in Dalmatia and evading a marriage plot concocted by her mother, Esther returned to Lucie and Belgium: "“Deep in my heart I knew that if I accepted Lucie's invitation it would be for keeps." 15

Lucie and Esther lived together in Liège from the mid1920s in a ramshackle house; however they labelled, or refused to label, their relationship, or dealt with differences of age (Lucie was nearly twenty years older), class, and nationality, this was clearly a partnership. ${ }^{16}$ Esther felt "an overwhelming compulsion to stay with Lucie for good." She said that Lucie offered her purpose: "Wasn't she the solution to my problem of what to do with my life? Hadn't I been toying with the idea of doing something useful, but not as a detached do-gooder?" Serving Lucie's work would not be "soulless slumming." But

Hiercheuse et Député Socialiste (Huy, Belgium:Imprimerie Cooperative, 1952), available online at http://www.19141918.be/lucie_dejardin.php, accessed 10/17/2017; Carl Strikwerda, A House Divided: Catholics, Socialists, and Flemish Nationalists in Nineteenth Century Belgium (Oxford: Rowman and Littlefield, 1997), 387, 390; and Robert Abs, "Lucie Dejardin," Biographie Nationale de Belgique (Brussels), vol. 38, Supplement 10 (1973-74): 145-50. ${ }^{15}$ EBC autobiography, NLS Acc. 8695/1, p. 2 of unnumbered section which follows unnumbered section on visit to Dalmatia, which follows ch. 12.

${ }^{16}$ EBC autobiography, NLS Acc. 8695/1, ch. 5, p. 24, has an enticing but ambiguous moment: during a partial "breakdown" after leaving her arms recycling post, which she attributed to cumulative stress, she returned to Edinburgh:

“Consulted Murray Lyon, Edinburgh's well-known psychiatrist. He puzzled me with searching questions about my sex life. I hadn't an idea what he meant. Sex had something to do with men. So how could it possibly worry me?" 
this was clearly a relationship of deep emotional connection: "at our first meeting under Mary Kelsey's auspices in 1922, we, two people as unlike as possible, had known the shock of complete understanding. How could anything so absurd happen, against all odds? But it did." 17

Esther and Lucie bought-in Lucie's name because Esther, as a foreigner, was prohibited---28 Quai St Barbe with a loan from Esther's mother Alice to allow crucial repairs (on a later visit, the impressed Alice forgave the loan). ${ }^{18}$ In Liège, Esther Chalmers was in an industrial city with a rich history of left politics; before World War I, it was a center for radical émigrés from the Russian empire, especially Mensheviks, and "a supplier of small arms for the revolutionary underground." 19 This history left patterns in politics and daily life atop local patterns of industrial radicalism. At 28 Quai Ste Barbe, Esther and Lucie took on sitting tenants of considerable individuality and added others, including Lucie's sister and niece and, in the 1930s, German, Austrian, and Spanish refugees. ${ }^{20}$ Esther Chalmers set up a bookshop, the Librairie Chalmers, for

${ }^{17}$ EBC autobiography, NLS Acc. 8695/1, unnumbered section (see note 13 above), pp. 17, 18.

18 NLS Acc. 8695/14, p. 7. After Lucie's death intestate, her heirs unanimously agreed that 28 Quai St Barbe should remain EBC's; NLS Acc. 8695/110.

${ }^{19}$ Mark Mazower, What You Did Not Tell: A Russian Past and the Journey Home (New York: Other Press, 2017), 14243.

${ }^{20}$ EBC autobiography, NLS Acc. 8695/1, unnumbered section (see note 13 above), p. 20; another brief unnumbered section, partly typed on obverse of a 1978 letter from the Scottish Fisheries Museum, begins directly after the mention of refugees, has more on tenants; the following section discusses Lucie's sister Jeanette, niece Andrée, and the bookshop. 
"second-hand books for the impecunious," with help from Marius Truchard, a red-bearded and garrulous anarchist bookman. Truchard had been gassed in the war, liked a drink, and had exclusive distribution rights for Belgian distribution of the publications of the International Labour Organization. ${ }^{21}$ In addition to her role as Lucie Dejardin's overall aide (and ghostwriter for Lucie's speeches), Esther Chalmers took responsibility for a children's home and other services established by Belgian socialist women. ${ }^{22}$ When a new Belgian king was crowned in 1934, Esther attended the ceremony in the Chamber of Representatives; “... as I performed any number of wifely chores, I insisted on a wife's privilege and Lucie had applied for a ticket for me." 23

In acute danger from the approaching German occupation in 1940, Esther and Lucie narrowly escaped after a harrowing, complex, set of journeys-initially attempting to travel into France to offer assistance to fleeing Belgians--which ultimately led to Dunkirk beneath strafing German planes. In Belgium and on arrival in Dover, Esther flatly refused to go on without Lucie and successfully fought to keep Lucie out of a refugee camp. ${ }^{24}$

${ }^{21}$ EBC autobiography, NLS Acc. 8695/1, last section noted, pp. 3-6. For Truchard, see also http://militants-

anarchistes.info/spip.php?article13214, accessed 10/19/2017.

${ }^{22}$ NLS Acc. 8695/2, "draft chapter on EBC s involvement with the administration of a children's home at Glons/Mont Comblain-au-Pont, during the 1920s and 1930s, and a description of a fête du quartier in Liège, at which she was honored for similar work." "isep."

${ }^{23}$ EBC autobiography, NLS Acc. 8695/1, final section, p. 2. ${ }^{24}$ NLS Acc. 8695/4, "Exodus for Two." This 35-page long document is extremely vivid; clearly begun during the war (internal evidence) it may have been revised later. 
Lucie Dejardin died in 1945. After the war, Esther Chalmers gave thirteen "oraisons funibres" [sic] for "departed friends," including Lucie, numbering carefully those who were murdered during the war. ${ }^{25}$ She returned to Belgium to again engage in relief and reconstruction work. She received an MBE in 1954 for this work. ${ }^{26}$ She wrote a biography of Lucie in French. Lucie Dejardin, hiercheuse et député socialiste, was published in 1952; its title foregrounds Lucie's proud identification with her background (she had worked in mining; her brother Joseph was a miners' leader noted for his internationalism). The epigraph of this book is a line, translated into French, from Robert Burns. ${ }^{27}$

Esther Chalmers ultimately returned to Scotland where she lived in Anstruther, but across her life she maintained friendships with women she had first met in relief work, including sustained visits and travels. ${ }^{28}$ Her relationship with Grace Lindley, "Benj" in the nickname created during their early friendship in France, was especially close; they travelled together repeatedly and when Benj died, Margaret Scattergood

25 "Spirou" [Thérèse Foidart] to Hannah Chalmers Campbell, 27 November 1950, NLS Acc. 8695/21; see also NLS Acc. 8695/15(i), list of names of former coworkers in Belgium with their fates.

${ }^{26}$ Supplement to the London Gazette, 10 June 1954, 3278; NLS Acc. 8695/33 makes clear that this was specially in relation to her work for the Association Belgo-Britannique. ${ }^{27}$ http://www.1914-1918.be/lucie_dejardin.php; for Joseph Dejardin, see Striwerka, House Divided, especially 390.

${ }^{28}$ See, e.g., NLS Acc. 8695/5 (travel with Mary Kelsey), and the letters from Grace Lindley, Margaret Scattergood, Eleanor Dulles Lansing, and others in NLS 8695/27; for Dulles see also 329. For travels, NLS 8695/16 includes a timeline of travels abroad and companions. 
wrote Esther Chalmers with special commiseration. ${ }^{29}$ (Scattergood had settled in Virginia with Florence Thorne, Director of Research for the American Federation of Labor on a farm which, ironically, later became part of the headquarters of the CIA. ${ }^{30}$ ) Esther Chalmers shared her home in Scotland for some time with the Belgian Eugénie-Thérèse Foidart, nicknamed "Spirou," who provided drawings for Esther's family history. ${ }^{31}$

In telling a story of Esther Chalmers along these lines, one would explore further the work that she did in preserving and organizing letters and photographs from her companions in post-World War I relief work. One might write at greater length of connections and variations between Esther

${ }^{29}$ NLS Acc. 8695/27, Margaret Scattergood to EBC, 19

December 1964. Lindley was living in Lewes at the time of her death;

http://www.sibfordoldscholars.com/Magazines/1965.pdf, 27; accessed 10/17/2017.

${ }^{30} \mathrm{https}$ ://www.cia.gov/news-information/featured-storyarchive/2008-featured-story-archive/scattergood-thorne.html, accessed 10/17/2017; Scattergood's addresses are in NLS Acc. 8695/49 and 50, EBC's address books.

${ }^{31}$ Foidart, as "Spirou," is noted in letters to EBC from others and some notes; her full name is given, with credit for drawings for "Green Box," at NLS Acc. 8695/106; see also NLS Acc. 7109 and below, p. 29. See also https://www.familysearch.org/ark:/61903/1:1:QJ13-X1X5 (accessed 10/17/2017). Spirou ("squirrel") was a FrancoBelgian comic strip character, partner with a character named Fantasio, which began in 1938; see https://en.wikipedia.org/wiki/Spirou_et_Fantasio. EBC also had a very powerful, often painful, relationship with Madeleine Fillet of Liège who visited her in Anstruther; see EBC diaries in NLS Acc. 8695/44-47. 
Chalmers's life and that of her sister Alison. After her time with the Scottish Women's Hospitals, Alison Bell Chalmers lived in Europe for many years. She had taken a post as matron of a children's home in Croatia established by Katherine MacPhail of the Scottish Women's Hospitals, who remained in Serbia for many years before retiring to St. Andrews. (Esther Chalmers saved a press-cutting about a talk MacPhail gave in Ceres, Fife, in the early 1960s, about her war experiences). After World War I, Alison Bell Chalmers met and married a Russian, Vsevolod Vladimirovitch Volchaneski, a former army captain and amateur artist; through the 1920s and 30s she lived with him and his children near Dubrovnik. ${ }^{32}$ Alison and her household too ended in flight from Nazi advances-via Baghdad and India - and finally back in Scotland, where Alison settled in Anstruther, where she died in 1959. Esther preserved and organized Alison's account of that frantic journey from Nazi advances as well as many letters and photographs. $^{33}$

${ }^{32}$ EBC autobiography, NLS Acc. 8695/1, unnumbered section following ch. 12, pp. 1-7; "McPhail" is on p. 6; for MacPhail, see Sybil Oldfield, "Katherine MacPhail," in Elizabeth McEwan, Sue Innes, Sian Reynolds, and Rose Pipes, eds., The Biographical Dictionary of Scottish Women: From the Earliest Times to 2004 (Edinburgh: Edinburgh University Press, 2006): 242;

http://scottishwomenshospitals.co.uk/women/?a=M (accessed 10/17/2017); s. v. "MacPhail, Katherine Stewart," in

Catherine M. C. Haines, ed., International Women in Science: A Biographical Dictionary to 1950 (Santa Barbara, CA: ABC-Clio, 2001); for EBC's press-cutting, see NLS Acc. $8695 / 15$ (i).

${ }^{33}$ NLS Acc. 8695/20 contains many letters from Alison to EBC; NLS Acc. 8695/114 includes Alison's passport and a ts. written during World War II about her time in "Jugoslavia," 
One might integrate aspects of Esther Chalmers's family story with stories of women's war work, lives during and after the war by women involved with the Scottish Women's Hospitals and the Friends' war and post-war services, and stories of war's scatterings and re-gatherings, as well as with the story of Esther Chalmers and Lucie Dejardin's profound partnership of love and commitment. Alison Bell Chalmers Volchaneski can appear in this story not just as a literal sister but as part of a world of connections, which included lesbian partnerships, between women including Ada Fyfe, Mary Kelsey, Margaret Scattergood, Grace Lindley, and Thérèse Foidart. For Esther Chalmers, these networks came to be centered on a nexus of socialism rather than primarily under the label of "peace." In a lecture given during World War II, she explained her understanding of socialism as a commitment to the full flourishing of three oppressed "classes of individuals": "the child, the woman, and the worker." 34

II.

There are other ways one might organize and recount a life of Esther Chalmers. We could begin with family connections and with Scotland rather than moving so directly to war work, internationalist feminist and socialist politics, and all that Belgium became for Esther Chalmers. Indeed, one could take a cue from the introduction to the excellent inventory of Chalmers's papers in the National Library of Scotland (NLS).

"the black days of 1917" and "nursing in Salonica" and "Kosova," and the Volchaneskis' flight from Croatia.

${ }^{34}$ Undated ts. of "lecture in Hampstead to a small club of refugees and some $\mathrm{H}$ [ampstead] residents" regarding visit to Soviet Union in 1936. EBC reconsidered her views on the USSR by the late 1960s; see NLS Acc. 8695/40, EBC pocket diary for 1968, page for March 10-16. 
This begins by providing a highly condensed evocation of the kind of families into which Esther was born:

Esther Barbara Chalmers [EBC] was born in Edinburgh in 1894, the youngest of the six children of Sir David and Lady Janet Alice Chalmers. Her father was the first Chief Justice of the Gold Coast from 1869 to 1878 and was then appointed Chief Justice of British Guiana, a post he held until 1893, when he retired from the colonial judical [sic] service, although he continued to serve when called upon to do so, eg, in Jamaica in 1894 and Newfoundland in 1897 and as a Royal Commissioner to enquire into a native uprising in Sierra Leone in 1898. Her mother's side of the family was no less distiguished [sic]: Esther Chalmers's maternal grandfather was James Lorimer, Professor of Public Law at the University of Edinburgh and two of her uncles were Sir R S Lorimer and J H Lormier [sic] RSA. ${ }^{35}$

As this introduction suggests, we can locate Esther Chalmers within some specific pedigrees of public life as well as strongly implying an inheritance of considerable class privilege, even if we didn't yet know anything about how or when that privilege had accumulated. Her father's career in imperial service is foregrounded along with an implication of smooth official recognition of his eminence. Despite the slight weighting of the Chalmers side in this account, there is an enticement to expand on the Lorimer side; both sides suggest using Esther Chalmers's life and archive to explicate some

${ }^{35}$ NLS, "Inventory," Acc. 8695. I am indebted to Geoff Eley for drawing my attention to the uses of this particular paragraph. 
aspects of Scottish cultural history in the nineteenth and early twentieth centuries.

As the summary notes, Esther's grandfather, James Lorimer (1818-1890) — the son of a factor--became Professor of Public Law at Edinburgh; his wife, not named in the summary, was Hannah Stodart (1835-1916). The summary notes two of their children's names and, aided by small markers of distinction ("Sir" and "RSA"), implies that these are names which may already signify and place Esther Chalmers. in elite circles. The summary provides perfectly reasonable concision and signposting, but I suggest taking it as a starting place for an expanded and revised account of Esther Chalmers's archive of her family.

As the birth/death dates above signal, James Lorimer was considerably older than Hannah Stodart. By the time of their marriage in 1851, James had been admitted to the faculty of advocates and was steadily publishing on legal issues although he did not become professor of law until 1862; throughout his early career, he had benefited from patronage whilst making a mark for himself in speaking and writing on behalf of reform of the Scottish universities ${ }^{36}$ Hannah Stodart, although scandalously younger-only sixteen when she married--was part of the social world of law into which James Lorimer had entered; she was the daughter of John Riddle Stodart and Jemima Henrietta Brown; her father was a Writer to the Signet. James and Hannah Stodart Lorimer produced a family of children who included the extremely successful painter John Henry Lorimer (1856-1936) and the great

${ }^{36}$ Information here and following is, unless otherwise noted, drawn from John W. Cairns, "Lorimer, James (1818-1890)," Oxford Dictionary of National Biography [ODNB], Oxford University Press, 2004; online edition, May 2011, https://doi.org/10.1093/ref:odnb/17016, accessed 5/17/2018. 
architect Robert Stodart Lorimer (1864-1929). ${ }^{37}$ Their eldest son, James (1852-1898), went into law and emigrated to South Africa, leaving few traces in Esther Chalmers's papers. ${ }^{38}$ Their three daughters were Esther's mother Janet Alice (1857-1951), known as Alice, and her aunts Hannah Cassels (1854-1947) and Carolina Louise, known as Louise (1861-1946). ${ }^{39}$ Esther Chalmers's grandparents also produced a legacy in the form of a place that became an archive: James and Hannah Stodart Lorimer took, almost on a whim, the lease of a then disused and moldering Kellie Castle in Fife, which they restored and made a family home, garden, and collection of works. Reflecting on the initial state of her home with Lucie Dejardin, Esther Chalmers remarked "Hadn't my grandfather fallen in love with Kellie Castle in just such a parlous condition? At any rate 23 Quai Ste Barbe didn't have trees growing out of the walls as had Kellie." 40 Kellie Castle is now a property of the National Trust of Scotland after passing through more

${ }^{37}$ See below for more, but these uncles of EBC are in the ODNB; see Anne Anderson, "Lorimer, John Henry (18561936)," ODNB (online ed. May 2011), https://doi.org/10.1093/ref:odnb/67596, accessed 17 May 2018, and David M. Walker, "Lorimer, Sir Robert Stodart (1864-1929)," ODNB (online ed., May 2011), https://doi.org/10.1093/ref:odnb/34600 accessed 5/17/2018. ${ }^{38} \mathrm{EBC}$ was a young child when he died and may never had had direct contact with him, but NLS 8695/140 contains photographs related to this uncle and EBC's notes on family history include him, e.g. NLS 8695/81.

${ }^{39}$ Dates drawn from NLS Acc. 8695 and confirmed at Scotland's People.

${ }^{40}$ EBC autobiography, NLS Acc. 8695/1, p. 20. 
generations of Lorimers; it is a site of considerable display of the Lorimer artistic legacy. ${ }^{41}$

Despite the bland and even officious tone in which I have presented this family background, this frame of lifewriting easily opens into a story of Esther Chalmers's inherited and lucky location in networks, including familial ties, of women rather than of famous men. One such opening lies both inside and outside the papers in the NLS. In 1971, "E.B. Chalmers" published an essay in the Times Literary Supplement, "Mrs Carlyle's Letters to John Stodart," which has suffered from two errors of attribution since: the TLS's online historical archive both combines it with an (unsigned) and separate review by Kenneth Allott in its formal citation and assumes that "E. B. Chalmers" was Eric Brownlie Chalmers, a writer on economics. ${ }^{42}$

${ }^{41}$ See https://www.nts.org.uk/Visit/Kellie-Castle/; http://www.scottish-places.info/features/featurefirst40.html ; http://www.undiscoveredscotland.co.uk/pittenweem/kelliecast le/index.html all accessed 10/20/2017; brochure, "The Lorimers: A Family of the Arts in Fife," an exhibition for the 1983 St. Andrews Festival presented by the Crawford Centre for the Arts, University of St. Andrews, 9 February-13 March 1983. See also Peter Savage, Lorimer and the Edinburgh Craft Designers (Edinburgh: Paul Harris Publishing, 1980). The website https://www.upward-onward.com (accessed $5 / 18 / 2018$ ) discusses the family in relation to Kellie and other sites but largely concentrates on the prominent male artists: John Henry, Robert Stodart, and Hew Lorimer.

${ }^{42}$ E. B. Chalmers, "Mrs Carlyle's Letters to John Stodart," Times Literary_Supplement, 25 June 1971: 739-41. For the online version and muddled citation, see http://find.galegroup.com.proxy.lib.umich.edu/tlsh/infomark. do? action $=$ interpret\&source $=$ gale $\&$ tabID $=$ T003\& prodId $=T L$ SH\&userGroupName $=$ umuser $\& d o c P a g e=$ article $\&$ search $T y p e$ 
E. B. Chalmers's essay begins with a tease about the fullness of, and gaps in, stories and archives.

A visit to my aunt Louise Lorimer was apt to become a literary murmuration: of Charlotte losing her head in Brussels; of Louise falling off the Cobb; of meeting Mark Twain and his family--'the best type of Americans'--on her way to visit the Austrian novelist Dorothea Gerard in 1890. She might intone 'The Owl and the Pussycat...", read a verse of her ballad 'The Braes o' Menstrie,' or one of her lyrics from 'The Trumpeter'. She might even display her greatest treasure, a note from R.L.S., but never once did she mention the letters of Jane Welsh Carlyle to her grandfather John Riddle Stodart.

E. B. Chalmers's introduces her aunt with multiple references to her knowledge, work, and connections en route to establishing that Louise's mother, and thus Esther's own grandmother, had her own connections to literary history through the Stodart line rather than only through her marriage to the proliferating Lorimers. ${ }^{43}$ E. B. Chalmers takes the

$=$ BasicSearchForm\&docId=EX1200373491\&type=multipage $\&$ contentSet=LTO\&version $=1.0 \&$ finalAuth $=$ true $($ accessed 10/20/2017).

43 Jane Welsh, later Carlyle, was friends in Haddington with a family of Lorimers, the family of the Reverend Robert Lorimer but there was no meaningful connection between two sets of Lorimers; they were on different sides in the Disruption. See David G. Ritchie, Early letters of Jane Welsh Carlyle, together with a few of later years and some of Thomas Carlyle, all hitherto unpublished (London: Swan Sonnenschein, 1889); and Thomas Carlyle and Jane Welsh Carlyle, The Carlyle Letters Online [CLO], ed. Brent E. 
chance to depict her maternal great-grandmother, Jemina, as a "strikingly handsome... would be bel esprit" who captured her husband away from Jane Welsh by fiat and whose "piercing eye" and "astringencies" thereafter ruled the household to the extent that James Lorimer and Hannah Stodart eloped rather than face her. ${ }^{44}$ E. B. Chalmers concludes her essay by reprinting a letter to her great-grandfather from a friend, after both Jane Carlyle and Jemima Stodart were dead, which claims that Jemima and Jane were alike in being unhappy as well as "strong minded." 45

Esther Chalmers elsewhere tells us even more about Jemima Brown Stodart's female descendants, from Esther's grandmother and great-aunts through her aunts, mother, and sisters. Esther's aunt Louise Lorimer, "clever as a monkey," is one of the more flamboyant: she wrote and travelled extensively, translated, and spoke and published on Scottish history, poetry (including a talk on "Scottish Women PoetsNew and Old"), and generally did as she liked, including converting to Roman Catholicism. ${ }^{46}$ She was at least

Kinser (Durham: Duke UP, 2007-2016), www.carlyleletters.org.

${ }^{44}$ EBC, "Mrs Carlyle's Letters," 739, 740. EBC is drawing here in part on James Lorimer's memoir as quoted in EBC, "Green Box,"292-93. There is more than a hint that Jemima Brown Stodart could reasonably have understood James Lorimer to be flirting with her before he ran off with her daughter; EBC, “Green Box," 292-93.

${ }^{45}$ EBC, "Mrs Carlyle's Letters, 741; letter from "S. Stirling," 20 July 1867.

${ }^{46}$ For monkey simile, see EBC, "Green Box," 230. NLS Acc. $8695 / 137$ contains miscellaneous papers by and about Louise Lorimer; the paper on Scottish women poets is a tss. of 36 pages which runs from anonymous early women through Mary Queen of Scots and $18^{\text {th }}$ century writers to Christine Orr 
intermittently a member of the Edinburgh Ladies' Debating Society. ${ }^{47}$ Esther Chalmers is frank that Louise was "[n]o regular writer, but as the spirit moves her she contributes an occasional article to the monthly literary reviews." She admires Louise's embroidery as part of the family project of refurbishing Kellie Castle into a place of art. ${ }^{48}$

Louise's travels to Austria and Poland were connected at least in part to her friendship with Dorothea Gerard, as E. B. Chalmers noted; as it turns out, this is not just a reminder that one might explore Esther Chalmers's archive for the history of "minor" women writers and their networks in the nineteenth century but, in fact, E. B. Chalmers's reference has already led to such work. The TLS essay led to a long and very friendly correspondence between Esther Chalmers and Robert Lee Wolff, then a professor of history at Harvard, which lasted until his death. Wolff was fascinated by Gerard, Louise Lorimer, and other "minor" Victorian writers. Wolff's historical specialty was the history of the Balkans-where he had significant experience during World War II. Like Esther Chalmers, he combined highly grounded experience of

and Violet Jacob; another tss., of 31 pages, is headed "On Some Women Poets of Today (From Sappho to Violet Jacob)"; for her conversion, see note at Acc. 8695/81, for 1914.

${ }^{47}$ For Louise's membership, see K. A. Kelman, "Female 'Self Culture' in Edinburgh: The Ladies' Edinburgh Debating Society. PhD thesis, 2002, Queen Margaret University, 240; for the Society, see also Lettice Milne Rae, ed., Ladies in Debate: Being a History of the Ladies' Edinburgh Debating Society, 1865-1935 (Edinburgh: Oliver and Boyd, 1936), and Carly Sarah Wood, "Women Debating Society: Negotiating Difference in Historical Argument Cultures," Ph.D. dissertation, University of Pittsburgh, 2010.

${ }^{48}$ EBC, "Green Box," 262-63, 275. 
twentieth-century histories of war with deep knowledge of other times and places, in his case, nineteenth-century British culture. Esther Chalmers preserved his letters, and he left a major archive of Victorian fiction which includes books he bought from or was given by her. ${ }^{49}$ Archives accumulate and ramify beyond Esther Chalmers's own.

Louise Lorimer cannot be figured - and is not figured by Esther Chalmers---as an outlier in her family because of her creativity, travels, or connections to other places. Esther was part of the third generation of women in her family to have participated in the movement for women's university education even if she was the first to take a degree; her grandmother Hannah and her mother Alice studied through the Edinburgh Ladies' Educational Association. Despite her exasperation with her own university studies, Esther Chalmers carefully noted and preserved the history of women's university education in Edinburgh in her notes and files. ${ }^{50}$ She saved a scrappy memoir by her older sister, Hannah Anderson Chalmers Campbell (1882-1974), which emphasizes Hannah Stodart Lorimer's musical gifts, her "wonderful power of expression in the use of words," and her frankness; pervasively, family writers present Hannah Stodart Lorimer as a full participant in the Kellie Castle project. ${ }^{51}$ Hannah Chalmers

${ }^{49}$ Wolff's letters to EBC are collected in NLS Acc. 8695/36; for Wolff and his collection, see http://www.hrc.utexas.edu/collections/books/holdings/wolff/ (accessed 10/21/2017) and Wikipedia, s.v. "Robert Lee Wolff."

${ }^{50}$ NLS Acc. 8695/251 for Janet Alice Chalmers's certificates; for EBC's exasperation, EBC autobiography, NLS Acc. 8695/1, p. 4; for an example of preservation and chronicling, NLS Acc. 8695/334. The frontispiece of "Green Box" is a photograph of EBC when she took her degree.

${ }^{51}$ NLS Acc. 8695/117. 
Campbell gives a first-hand account that Esther could not of their mother's life in Guyana as wife of the Chief Justice, including her charitable projects there, but Esther's memoir notes Alice Chalmers's voluntary work in Edinburgh, including her connection to the Bruntsfield Women's Hospital (founded by Sophia Jex-Blake). The archive also includes sketches and watercolors by "J.A.C."-Janet Alice Chalmers. If Esther's autobiography woefully notes her mother's disappointment that she did not marry, it hardly depicts her mother's marriage as the whole of her life. ${ }^{52}$ It also tells us that, at Netley, Esther worked with a Guyanese woman who had first been encouraged to train as a nurse by Alice Chalmers in Georgetown. ${ }^{53}$

Esther Chalmers's archive is even more pointed in documenting the talent and seriousness of her aunt, Hannah Cassels Lorimer im Thurn. Hannah's marriage to Everard im Thurm, a colleague of her father's in the Colonial Service in 1895, took place when Esther was only a year and half old--that is, Esther Chalmers draws attention to the fact that she is collecting and narrating this aunt's life, not just relating her own memories ${ }^{54}$ Evarard im Thurm's work subsequently took the couple from Scotland and Guyana to Ceylon, Vanuatu, and Fiji before retiring to Cockenzie House, Port Seton. It is easy to register (Sir) Everard's prestige; in obituaries, he was lauded as a botanist, explorer, and scientist rather than just an agent of government. 55 But "Lady im Thurn" is not cast into the

${ }^{52}$ EBC autobiography, NLS 8695/1, ch. 2, p. 15; ch. 4, p. 1.

${ }^{53}$ EBC autobiography, NLS Acc. 8695/1, ch. 5, p. 12; see also 8695/15(ii). ${ }^{54}$ NLS Acc. 8695/81.

${ }^{55}$ E.g. https://www.therai.org.uk/archives-andmanuscripts/obituaries/everard-im-thurn (accessed 10/21/2017); https://www.kew.org/blogs/library-art-andarchives/everard-im-thurn-and-lost-world (accessed 
shadows in the archive of her niece. Esther Chalmers repeatedly notes that Hannah Lorimer was not just another keen participant in the decoration of Kellie Castle but had serious artistic ambitions beyond its walls. Esther Chalmers explains that, at Kellie:

An easel, a stand with a clay head wrapped in damp cloth are Aunt Hannah's property. A near professional artist, Aunt Hannah will have a season in the studios of Paris in 1891, work as hard as brother Jack and have pictures accepted at the Royal Scottish Academy. Many years later, the studies she has made of orchids and other tropical flowers in British Guiana and Fiji will be recognized as valuable botanical documents and welcomed by the Edinburgh Botanical Gardens museum.... A rarely versatile experimenter in materials, she does not stop at the moulding of soft clay, but attacks hard wood. Designs on bookcases, stools, and racks emerge from her hammer and chisel to beautify Kellie. ${ }^{56}$

10/21/2017). Im Thurn's expedition to Mount Roraima in particular has been explored for its cultural uses beyond his own documentation; see Rosamund Dalziell, "The Curious Case of Sir Evarard im Thurn and Sir Arthur Conan Doyle: Exploration and the Imperial Adventure Novel, The Lost World," English Literature in Transition, 1880-1920 45:2 (2002): 131-157; see also Dalziell, "Evarard im Thurn in British Guiana and the Western Pacific," in Peter Hulme and Russell McDougall, eds., Writing, Travel, and Empire: In the Margins of Anthropology (London: I. B. Tauris, 2007), 97118. Evarard im Thurn has a significant presence in the historical and anthropological literature on Fiji.

${ }^{56}$ EBC, "Green Box," 262-63 
Hannah Lorimer had exhibited paintings at the Royal Scottish Academy at the same time as her brother, the more famous John, and at least once she got in and he did not. ${ }^{57}$ She continued to paint and exhibit during her life as a diplomat's wife. Her niece's collection includes sketches as well as letters to and from her aunt, including letters from Cornelia Sorabji. ${ }^{58}$ In telling some stories of some of Esther Chalmers's female relations--and I am leaving out many others--I am clearly suggesting that attending only to the famous uncles, J. H. and R. S., occludes both a multi-generational family's privileged participation in Victorian and Edwardian, Scottish and imperial, artistic and public life and the lively confidence with which women in this network contributed to and benefited from Edinburgh's particular place in the history of women's education. Paying attention to this family background undermines any temptation to over-emphasize rupture, break, or rebellion as tropes for narrating Esther Chalmers's life, e.g. as an escape from a late Victorian destiny of domesticity. From some angles, Esther Chalmers's family background, and that of the class-fraction the women of her family inhabited or entered, looks not like a fate from which she escaped but foreshadowing and enabling of the life she went on to live.

III.

This mapping of continuities rather than disruption expands if we pay attention to some extra-familial and para-familial relationships to which Esther Chalmers insistently draws attention. Those relationships were created and enabled by family.

Esther Chalmers's unpublished autobiography places great emphasis on the imbrication of her family with a French

${ }^{57}$ NLS Acc. 8695/81, item 13.

${ }^{58}$ NLS Acc. 8695/125, 126, 127. 
pair of sisters, Blanche and Aline Bessire--fondly known as the Tantes--and their niece Jeanne Guillaume. The Bessires kept a small school in Edinburgh, at the corner of Manor Place and Rothesay Terrace, known as The French School; conducted entirely in French, it had drawn the dedication of David and Alice Chalmers for the education of their daughters. This was by no means the only or most obvious choice for the Chalmers daughters' education (the three Chalmers sons were sent to Edinburgh Academy and Ardvreck.). ${ }^{59}$ By the time their eldest daughter, Hannah Helen, born in 1882, was of school age, Edinburgh was burgeoning with educational possibilities for girls of the Chalmers's class, including those like St. George's which were explicitly tied to the project of women's higher education. ${ }^{60}$ But apparently the Chalmers parents, and perhaps especially David Chalmers, were "captivated" by the Bessires. ${ }^{61}$ The relationship between the families extended far beyond term-time. Alice Chalmers and her daughters-and later sometimes Esther and other girls-repeatedly travelled with the Bessires as (undoubtedly paid) guides and arrangers of housing and excursions during holidays. The relationship included Lorimers as well; Louise and John Henry came for visits to the Bessires' house in Normandy and Robert Stodart

${ }^{59}$ EBC, "Green Box," 355.

${ }^{60}$ See Alasdair Robert, Crème de la crème: Girls' schools of

Edinburgh (London: Steve Savage, 2007) for an overview; and Nigel Shepley, Women of Independent Mind: St. George's School, Edinburgh, and the Campaign for Women's Education, 1888-1988 (Edinburgh: St. George's School for Girls, 1988).

${ }^{61}$ EBC, "Green Box," 355; EBC is quoting Hannah Chalmers Campbell. 
Lorimer designed a villa for them at their home near Mentone. ${ }^{62}$

Esther Chalmers later claimed that the allure of the Bessires' school for her parents was not predominantly its intellectual standards:

[T]he Bessires well knew our parents were not, as a rule, very interested in scholastic attainments.

What they wanted for their daughters was a certain standard of behavior, of deportment to use an outmoded Victorian/ Edwardian word. This included training in the art of avoiding those chilly silences that must never never be allowed to occur in polite society. ${ }^{63}$

And yet... Esther Chalmers goes on to make clear that the "social" education she received from the Bessires was not limited to social graces. Blanche Bessire displayed an admirable sense of fair play: "she wore the swishiest of taffeta petticoats, chosen on purpose to warn us of her approach. That was the kind of person she was." Blanche Bessire was an early woman graduate of the Sorbonne, taking a degree in literature and philosophy alongside her blind brother, Emile, explaining

${ }^{62}$ EBC autobiography, NLS Acc. 8695/1, section following ch. 3 (c. 1907), pp. 3-4; for the villa, see http://www.scottisharchitects.org.uk/building full.php?id=21 2172 (accessed 10/22/2017).

${ }^{63}$ EBC autobiography, NLS Acc. 8695/1, ch. 3, p. 8; see also ibid., ch. 3, p. 6; EBC describes her mother as possessing "true Lorimer gregariousness" but her father as much more socially awkward; the emphasis on social graces may have come from both for different reasons; ibid., ch. 1, p. 8. 
that she was doing the reading for him in any case. ${ }^{64}$ "One of the Sorbonne's earliest female graduates, she had to 'show proficiency in needlework' and liked to tell us how she got by with a piece of canvas covered with enormous stitches." 65 Esther commended the rigor of her own education in French literature and thought especially and in terms which carry a charge: the Bessires and their staff gave her "[i]nvaluable training for what was to come many years later when I would skim rapidly through stacks of newspapers, Government documents, reports, etc. and pounce on any points that might be necessary or helpful to Lucie Dejardin, the Belgian M.P. for whom I bottlewashed from 1923 till the invasion of Belgium on May $10^{\text {th }} 1940 . " 66$

Beyond this education through the formal curriculum, the Bessire family brought the Chalmerses into contact with European radical traditions. Jeanne Guillaume, who taught at the school, was the "Tantes" niece; Jeanne's mother, their sister Léopoldine, was married to George Guillaume, who had been a Swiss volunteer in defense of France and the Commune in 1870 and 1871. Jeanne was thus the niece of James Guillaume, a leader of the anarchist side in the First International, translator of Bakunin and friend of Kropotkin. ${ }^{67}$

${ }^{64}$ For Emile Bessire, see https://diju.ch/f/notices/detail/4370, accessed 10/22/2017, and items, including photographs, EBC preserved in NLS Acc. 8695.

${ }^{65}$ EBC autobiography, NLS Acc. 8695/1, ch. 3, p. 1.

${ }^{66}$ EBC autobiography, NLS Acc. 8695/1, ch. 3, p. 6.

${ }^{67}$ For the Guillaumes, see La Famille Guillaume at http://www.montmollin.ch/pub/Guillaume.pdf; materials are more abundant on James, e.g. https://www.marxists.org/reference/archive/guillaume/index.h tm; https://robertgraham.wordpress.com/2016/05/29/fromanarchism-to-syndicalism-the-journey-of-james-guillaume/ and http://jguillaume.hypotheses.org, all accessed 10/22/2017. 
Esther Chalmers was very close to Jeanne, from whom she heard of Jaures, Kropotkin, and others whom Jeanne met through her uncle. Esther went on to meet this older generation of the family (as well as the Tantes's brother Emile), and she never lost contact with the Tantes. Later, in Liège, she would attempt, unsuccessfully, to help Jeanne Guillaume print the work of her uncle James, especially his "Histoire de la Seconde Internationale." $" 68$

This familial and extrafamilial nexus, not trivially, ensured that Esther Chalmers, like the other women in her family, was utterly at home in French long before she began post-war relief work. It expands the contexts of Esther Chalmers's enthusiasm for Europe and cosmopolitanism. It reminds us too that dismissive generalizations about girls' education in private schools in Edinburgh or elsewhere can forestall actual investigation of women school-keepers' erudition, talent, and sometimes highly distinctive cosmopolitanism. ${ }^{69}$ Esther Chalmers's knowledge of socialism, anarchism, and profound political commitment began before the war. And again, this is not a story of rebellion against a family but one of knowledge and experiences which that family itself made possible and even cherished. Crossgenerational cosmopolitanism and international engagements are stitched together with specific Scottish histories of

${ }^{68}$ EBC autobiography, NLS Acc. 8695, penultimate (unnumbered) section, p. 6. According to EBC, the history was printed but uncirculated when all copies were lost in a fire.

${ }^{69}$ This is a large topic about which there is more to say, but I hope to flag that the dismissal of elite girls' education before some arbitrary time-point as only about "accomplishments," understood as inherently trivial, should be challenged on multiple grounds. 
education, women's rights, and even a flash of Scottish architecture in the south of France.

IV.

These stories pervasively (if, until now, implicitly) share something which must not go unremarked: the material for these histories was created, organized, and shaped by Esther Chalmers. I have offered overlapping accounts of some lives but, more pointedly, a ramifying account of an archive, including the "intertext" of an archival record created by a librarian, the NLS's inventory of "Esther Chalmers's" papers. While, sadly, the name of the librarian who created the inventory has not been remembered, it seems clear that much organization, as well as overt labeling, was done by Esther Chalmers. It was her work which preserved such rich materials on other women, including some of the papers of her sisters, aunts, and grandmother, and letters from her own network of women co-workers and friends. It was especially her work which created a typescript autobiography, however incomplete, and which saved drafts. It was Esther Chalmers who wrote a long, bound typescript family history, "Out of the Green Box," for her younger relatives on the Chalmers side and kept the notes and early drafts of that work too. It was primarily Esther Chalmers who annotated photographs to identify dates, locations, and subjects, including the Bessire family; who conserved sketches and watercolors; and who kept and filed miscellaneous printed texts, whether an article by her aunt Louise, a pamphlet on children's homes in Belgium, a funeral programme, material from Le Droit Humain, or the minutes of ARP and Civil Defense meetings from Fife during the war.

Esther Chalmers was not a professional archivist, but she was a committed one, and as in the case of Robert Lee Wolff, she enabled the archival practices of others. It is worth underscoring some elements of her life in Liège: her work with 
Marius Truchard, including the creation of the Librairie Chalmers (forcibly lost during the war) and her attempts to help preserve the work of James Guillaume. We should, as well, return to her "retirement" to Anstruther. It would be easy to think of this as a retreat to a picturesque village near some childhood haunts and relatives in Fife. But Anstruther also combines aspects of Esther Chalmers's adult history: it was among the Fife fishing villages simultaneously associated with artists and with intense working-class history and pride; it is, as well, part of a land- and seascape deeply marked by war and the militarization of place. Relative proximity to St. Andrews and Dundee, as well as Edinburgh, also gave her easy connections to university life, notably, to the world (emphasis intentional) of legal scholarship in which her Lorimer grandparents and her father had participated. Elizabeth Fellowes Willock and Ian Douglas Willock---respectively a solicitor and a professor of jurisprudence at Dundee--were close friends and Esther Chalmers was very impressed by Angeline Kamba (wife of legal scholar and later vicechancellor Walter Kamba), a legal librarian and, later, national archivist of Zimbabwe, whom she met when they lived in Anstruther. ${ }^{70}$

${ }^{70}$ The Willocks are, for some reason, almost always spelled Willocq in EBC's diaries. They were frequent visitors and Elizabeth seems to have handled EBC's will; for Ian Douglas Willock, see https://www.scotsman.com/news/obituaries/obituary-iandouglas-willock-legal-academic-1-3142727 and http://www.scolag.org/system/files/2013_SCOLAG_236239.pdf; for the Kambas, see https://www.scotsman.com/news/obituaries/walter-kamba-1905935; http://caineprize.com/blog/2017/9/28/a-tribute-toangeline-kamba-from-the-council-of-the-caine-prize-forafrican-writing; http://www.sundaymail.co.zw/dr-angeline- 
Ironically, one aspect of Anstruther's history could (and still can) obscure her own family history and even falsely overwrite it. Anstruther was the birthplace of Thomas Chalmers (1780-1847), minister, professor, and leader of the Disruption, a name of enormous power in Scottish history and no relation to Esther Chalmers at all. Thomas Chalmers's name marked Anstruther's great church; Chalmers Brae, a central street; and the Easter Chalmers lighthouse at the harbor. ${ }^{71}$ In Anstruther, "Miss Chalmers" might easily have been thought as perhaps a spinster descendant of that family rather than associated with the Lorimers; even today, in speaking with local historians, one needs to quickly explain that she was a different Chalmers. But she left her archival mark nonetheless: she was a supporter of the Scottish Fisheries Museum, mooted in 1965 and founded in 1967. ${ }^{72}$ Some traces of the Museum are in her own archive in the NLS in Edinburgh, but her name can be found on a door in the Museum. It is the door of the Research Library which contains, e.g., boat registers, many thousands of photographs, government reports, and other materials documenting fisherfolk in work, community, war, and family all around Scotland. A brass plaque reads, in part, "The creation of this library was made possible by the generosity of Miss Esther B. Chalmers, M.B.E.,

kamba-dies/ (all accessed 5/17/2018); and NLS Acc. 8695/45, EBC pocket diary for 1980, entry for 29 June 1980.

${ }^{71}$ Though the church is gone, many records of it endure; see https://canmore.org.uk/site/70072/anstruther-easter-chalmersmemorial-church (accessed 5/14/208) and a memorial garden with sculpted head of Thomas Chalmers was dedicated in 2013.

$72 \mathrm{http}: / / \mathrm{www}$.scotfishmuseum.org/history-of-themuseum.php (accessed 5/16/2018); NLS Acc. 8695/284, in EBC's papers, is a copy of the 1983 annual report of the museum. 
Chevalier de l'Ordre de Leopold II, M.A."73 Her Belgian life and its recognition, and her education, are marked (and perhaps ensure that she not assumed to be one of the other Chalmerses?), but what lies behind the door enables exploration of the lives of others, made possible in part by her.

Esther Chalmers's archive in the NLS was clearly a distinct as well as distinctive project: these are the materials she wrote, kept, sorted, and annotated. These are the materials whose destiny she organized. This preservation of papers and creation of accounts should not be regarded either as miscellany nor, through focus on the family papers alone, as a performance of familial piety to be expected of an unmarried daughter of a house; it is far more diverse than that. She could have put the fate of this material into the hands of family members or picked out for preservation only the materials that might enter the Lorimer archival vortex of Kellie Castle. ${ }^{74}$ She didn't - she kept family history, political life, friendship, and research together. She took no chances, saving drafts and duplicates. In an act moving and protective, Esther Chalmers deposited a copy of "Out of the Green Box," which she had

${ }^{73}$ http://www.scotfishmuseum.org/library-and-researcharchive.php (accessed 5/16/208); plaque viewed and photographed 14 May 2018.

${ }^{74}$ There were occasional tensions about that vortex; on 22 June 1946, EBC's brother Patrick Chalmers wrote Alison Chalmers Volchaneski asking to borrow their grandfather's memoir: "I understand it belongs to Christopher [Lorimer], but as he and I are not on speaking terms, and never likely to be, I don't want to have it go back to him and then have to ask his Lordship's permission to see it. In fact I shouldn't get it that way; nor would I ask. But I will send it back to Nan [Hannah Chalmers Campbell], or you, as soon as I have taken a copy." This letter ended up in EBC's hands; NLS Acc. $8695 / 21$. 
written for the younger generation of her family, most directly the children of her brother, in the NLS well before her death. That copy had belonged to her "very dear friend and partner, Spirou Foidart," whom she thanks in an inscription for her design skills and "her unstinted help \& patience." She later added the date 1965, and a further note: "Thérèse (Spirou) Foidart/born 12.4.1898 at Liège/died 5.1.1978 at Camelon Hospital," providing historical specificity and provenance. She ensured that this loved copy of the book and the name of a loved person were conserved. ${ }^{75}$

And there is more. I want to highlight some clusters of material in that archive to which I have not yet granted prominence in this essay. These materials---and Esther Chalmer's commitment to them-connect, underline, and extend the range of Scottish international lives.

V.

Two sets of materials are, at first, family stories about men.

As noted earlier, Esther Chalmers's grandfather, James Lorimer, had become Professor of Public Law at Edinburgh. He died in 1890, i.e. before Esther Chalmers's birth. The son of a factor who benefited from his father's inheritance of money derived from the Dutch East India Company, as well the patronage of his employer, the earl of Kinnoul—and thus with a close link to the events around the Disruption, as it was the earl whose actions led to the Auchterarder case-James Lorimer was, not surprisingly, sympathetic to conservatism and patronage. He opposed not just universal suffrage but even

75 EBC, "Green Box," 1; the book is addressed to the children of her brother James Lorimer Chalmers, known as Giac or Jack, b. 1888. The copy EBC presented in January 1978 is NLS Acc. 7109; the NLS online manuscripts catalogue provides this information . 
the limited 1867 act. ${ }^{76}$ His role in the history of Scottish university reform in the 1850 s was more forward-lookingEsther Chalmers summarized the goals of the Association for the Extension of Scottish Universities as "to move beyond the pervading classics and foster the teaching of new subjects, even including the History of Art."77 His legal thought was similarly divided between conservatism and an interest in innovation; centered on ideas of natural law, which have not endured well, it was notable for its role in the development of theories of international law. ${ }^{78}$

More specifically, James Lorimer foresaw and argued for some form of international, at least European, government, a "permanent congress of nations," and an international court

${ }^{76}$ For the inheritance of resources, see http://archive.org/stream/lorimerscotland00stod/lorimerscotla nd00stod_djvu.txt (accessed 6/2/2018) as well as information on display at Kellie Castle. For the Auchterarder case and the Disruption more general, see entries in Nigel M. de S.

Cameron, ed., Dictionary of Scottish Church History and Theology (Edinburgh: T. and T. Clark, 1993); for James Lorimer on the disruption, see his tss., "The Family Story," in NLS Acc. 8695/138, 151-55; on suffrage, 147.

${ }^{77}$ EBC, "Green Box," 293-94.

${ }^{78}$ See Encyclopaedia Britannica, s.v. "Lorimer, James," online edition, 2007:

https://www.britannica.com/biography/James-Lorimer, accessed 10/27/2017. James Lorimer's major works are: The Institutes of Law: A Treatise on the Principles of Jurisprudence as Determined by Nature, 2 vols. (Edinburgh: William Blackwood, 1880); The Institutes of the Law of Nations: A Treatise of the Jural Relations of Separate Political Communities, 2 vols. (Edinburgh: William Blackwood, 1884); Studies National and International (Edinburgh: W. Green, 1890). 
of justice of some kind. James Lorimer was notable for the breadth and depth of his European engagement. He was on close terms with European scholars of law, with whom he was a founder of the Institute of International Law (Esther Chalmers's autobiography specifically notes that the foundation took place in Belgium). ${ }^{79}$ Esther Chalmers's older brother Patrick (1880-1953) claimed James Lorimer's importance in the pre-history of the League of Nations in newspaper cuttings Esther archived; Patrick added that, in his own career in the Foreign Office, he had proposed an arrangement for "interchangeability of citizenship" among a number of European nations at least for the duration of World War II, drawing on his grandfather's ideas ${ }^{80}$ Esther Chalmers's archive includes a typescript family history of the Lorimers by James Lorimer and an annotated text of a talk in which James Lorimer claimed a history of Scottish internationalism; miscellaneous other materials by and about him; Patrick Chalmers's letters; and some material from the 1970s regarding an ongoing skirmish with Lorimer relatives about the control and prominence (or lack thereof) of display at Kellie Castle of documents from Italy and Russia honoring James Lorimer. $^{81}$

James Lorimer's thinking about Scotland and Europe, international law and institutions, are part of a longer history

${ }^{79}$ EBC, “Green Box," 301-303.

${ }^{80}$ Patrick Chalmers to EBC, 25 July 1948, NLS Acc. 8695/21 and $8695 / 324$.

${ }^{81}$ For James Lorimer's memoir, see note 66 above; for James Lorimer on Scottish internationalism, see "Notes by Prof. James Lorimer" on the "Anglo-Mania,"” n.d., Acc. 8695/131; for the arguments with relatives, see Hew Lorimer to EBC, 2 February 1972 and 24 April 1972, and EBC note on letter of 16 May 1977 from Christopher Lorimer ("C. apparently thinks I am an imbecile! ..." all in NLS Acc. 8896/21. 
Esther Chalmers and her brother inherited. But it is crucial to highlight that James Lorimer's ideas about international law and international organizations, according to the contributors to a 2016 forum on his work and legacy, were not just infused by but fundamentally structured by a committed imperialist frame and deeply embedded racism. ${ }^{82}$ I draw attention to James Lorimer's legacy to Esther Chalmers not to redeem it but make explicit that the family intellectual and political heritage she preserved was both a history of Europeanness and an archive of empire and racism.

The second cluster of male-centered family materials in the archive is much larger. Esther Chalmers's archive contains writings by her father, David Chalmers-letters and his autobiographical writings in the form of his published memoirs of his "colonial service." ${ }^{83}$ But David Chalmers's centrality to Esther Chalmers's archive is greater than that: the longest text in the NLS Chalmers collection is Esther's family history for

${ }^{82}$ Stephen Tierney and Neil Walker, "Through a Glass, Darkly: Reflections on James Lorimer's International Law," introduction to symposium on "European Tradition in International Law: James Lorimer," European Journal of International Law 27: 2 (2016): 409-413. (doi:10.1093/ejil/chw018); the papers in the symposium are: Martti Koskenniemi, "Race, Hierarchy and International Law: Lorimer's Legal Science," 415-429; Gerry Simpson, "James Lorimer and the Character of Sovereigns: The Institutes as 21st Century Treatise," 431-436; Karen Knop, "Lorimer's Private Citizens of the World," 447-475; and Stephen C. Neff, "Heresy in Action: James Lorimers Dissident Views on War and Neutrality," 447-492. Koskenniemi's essay is particularly trenchant on Lorimer's racism.

${ }^{83}$ David Chalmers's papers can also be found in the University of Edinburgh Library; see https://archiveshub.jisc.ac.uk/data/gb237-coll-239. 
her Chalmers relatives, "Out of the Green Box." She explains that she had found, in "a large, green-painted box known to my generation as the Turkish soldier's chest," materials she had first seen decades earlier:

As relaxation from taking my degree in the 1920s I browsed among these oddments [of papers in her mother's house] sufficiently to realise that there lay the bones of the family story. I realized too---what was much more important to me---that ... [the box] must contain the story of my father, the man whom I had learnt from my mother to respect and admire but had never known. ${ }^{84}$

Esther Chalmers's impetus to write that history is far more than daughterly curiosity or familial emotion. The impetus is vindication and indictment. This history escapes and exceeds "Out of the Green Box."

To summarize with unforgiveable brevity: in 1898, David Chalmers - by then several years retired and frustrated by the "four walls of an Edinburgh house"--was asked to investigate events in Sierra Leone known as the "hut tax war," which he saw as "the opportunity ... to render a last valuable service to the community of Sierra Leone" only to find "his high hopes wrecked by political intrigue." 85 David Chalmers's report was intensely critical of the British government's actions

${ }^{84}$ EBC, "Green Box," 1.

${ }^{85}$ EBC, "Green Box," 1. 
in policy and action in startlingly frank terms. ${ }^{86}$ The report was viciously attacked and discredited before publication by the government in actions orchestrated significantly by Joseph Chamberlain. ${ }^{87}$ David Chalmers died soon after, but his widow-Janet Alice Chalmers - assisted by E. D. Morel, wrote and published a defense of his report which is (of course) included in the archive; Esther Chalmers drew on it as well. ${ }^{88}$ Esther Chalmers commended David Chalmers for his documentary work: he "[made] the fullest use of the nearly three hundred witnesses who [came] to his office... [and] record[ed] the rambling answers of women traders, relatives of

${ }^{86}$ Report by Her Majesty's Commissioner and correspondence on the subject of the insurrection in the Sierra Leone Protectorate, 1898 (London: Darling and Son, 1899); see also "Report on the insurrection in Sierra Leone Protectorate, and on affairs generally in the colony and protectorate, by commissioner Sir David Chalmers. Includes documentary evidence and verbatim transcripts of oral evidence," National Archives ref. CO 879/54/9, record at http://discovery.nationalarchives.gov.uk/details/r/C8869372, accessed 10/27/2017. For Janet Alice Chalmers's article, see "In Defence of Sir David Chalmers," The Nineteenth Century 47 (March 1900): 485-97. For these texts in EBC's archive, see NLS inventory.

${ }^{87}$ An attack on Chalmers's report appeared in July 1899; Harry L. Stephen, "The Sierra Leone Disturbances," Nineteenth Century 46 (July 1899): 475f. David Chalmers died on 5 August 1899.

${ }^{88}$ EBC, "Green Box," 444-445, says Morel "proceeded to make mincement of Stephen in a pamphlet, "The Sierra Leone Disturbances, a reply to Mr. Stephen'.” Bernard Porter cites this as "The Sierra Leone Hut-Tax Disturbances," in Porter, Critics of Empire: British Radicals and the Imperial Challenge (London: I. B. Tauris, 2008), 255, n. 2. 
missionaries, boatmen, policemen's widows, a shipwright, numerous farmers and headmen, a carpenter, etc. , etc." as well as his close questioning of government officials. ${ }^{89}$ His account, like hers, is accumulative and analytic.

While writing her account, Esther Chalmers corresponded with noted historians of Africa, especially Kenneth Little. ${ }^{90}$ She obtained and kept articles and references from scholarly work, including materials she could access in Belgium, especially those which helped her to understand Sierra Leonean actors. She kept her index-card notes. ${ }^{91}$ She gave a lecture (in French) on the issue as well as writing a pugnacious account in "Out of the Green Box."

David Chalmers cannot stand as the non-imperialist, non-racist counter to James Lorimer in a falsely unified narrative of Esther Chalmers's inheritance. His own published memoirs, which she included in her files, contain plenty of racist categorizations, especially from his time in Guyana. Nonetheless, in his own memoirs, his daughter's account, and in some much later re-visitings by scholars and others, David Chalmers's respect for African legal systems is notable; his report continues to be mined by historians of Sierra Leone. ${ }^{92}$

${ }^{89}$ EBC, “Green Box," 406-07.

${ }^{90}$ NLS Acc. 8695/31; NLS ACC. 8695/272 and 274 are copies of essays by Little.

${ }^{91}$ NLS Acc. 8695/64.

92 This is a literature beyond my range, but see, e.g., Magbailly C. Fyle, Historical Dictionary of Sierra Leone (Lanham, Maryland: Scarecrow Press, 2006), s.v. "Chalmers Report," 35-35; Sylvia Ojukutu-Macauley and Ismail Rashid, eds., The Paradoxes of History and Memory in Post-Colonial Sierra Leone (Lanham, Maryland: Lexington Books, 2013), especially Lansana Gberie, "The Chalmers Commission and the Truth and Reconciliation Commission (TRC) of Sierra Leone: Official Inquiries as Historical Memory," 101-126; 
My account of him is deliberately very brief here as an incitement to others to make use of the material in Esther Chalmers's archive for its value to historians of Scotland and Africa. In the context of my own arguments here, this cluster of materials stands as more evidence that Esther Chalmers's archive should be seen as a huge, engaged, unfinished work which often foregrounds histories of law, human rights, and internationalism as they run through and beyond other Scottish histories.

David Chalmers's remains in the NLS are not evidence for a story I can tell about West African history. But it is a story Esther Chalmers took enormous trouble to explore and even more trouble to preserve and to present. If her own life work can sometimes - with plenty of its own lacunae and biases-rebuke the limitations of her grandfather and her father, her archive discourages sharp divisions between the versions of her story with which I began--as internationalist feminist and socialist, on the one hand, and member of a multi-generational family network of women on the other. It refuses a neat opposition between "her" stories and the inscriptions of men in official histories and institutions. Indeed, it is partly through her father's activities - and the knowledge she accumulated in order to document him---that another woman appears in Esther Chalmers's archive.

Lynda Rose Day, Gender and Power in Sierra Leone: Women Chiefs of the Last Two Centuries (New York: Palgrave Macmillan, 2012); and Christopher Fyfe, "Documents Relating to the Sierra Leone Hut Tax Enquiry in the Sir David Chalmers Collection, University of Edinburgh," Africana

Research Bulletin 2:4 (1972); For one recent online engagement from the perspective of tax resistance, see "Arrogant Colonial Administrators in Sierra Leone Tax Fiasco," https://sniggle.net/TPL/index5.php?entry=21Jan12. 
Joanna Herbert was a Guyanese woman of color whom the Chalmers family met and employed in Georgetown during David Chalmers's term of service as chief justice of Guyana, born c. $1846 .{ }^{93}$ Esther Chalmers's autobiography begins by evoking her, albeit with an unfortunate attempt at phonetic spelling of her accent ("Mercy on da chile") and it largely refers to her by the family nickname of "Nana" (she was also known to the Chalmers children as "Hubbie," probably a child's version of "Herbert"). In "Out of the Green Box," Esther Chalmers briefly speaks for all of her siblings in saying that Herbert became "our dearest friend for the next thirty-six years" when she was hired in 1881 (Esther knew her for twenty-three years). Herbert travelled back and forth to Scotland with Alice Chalmers during David Chalmers's service in Guyana and then remained in Scotland after his retirement. ${ }^{94}$

Esther Chalmers's autobiography takes care to include a wider history: Herbert was the descendant of an African man "press-ganged from Africa to eat his heart out on a British Guiana sugar estate." Chalmers would not have shied from the word "enslaved"; she is making clear that, in her

${ }^{93}$ EBC autobiography, NLS Acc. 8695/1, p. 2, spells her first name "Johanna" but Hannah Helen Campbell Chalmers refers to her clearly as Joanna in NLS Acc. 8695/117, ts. memoir "My Mother." I shall follow that spelling, which is also in Scotland's People with a death date, 1917, and Herbert's own will. There is a photograph of her marked "Nana and Jack" in Guyana in NLS Acc. 8695/166 (Jack was EBC's older brother), and 4 or 5 photographs of her in Edinburgh at NLS Acc. 8695/148.

${ }^{94}$ EBC, "Green Box," 256. Hannah Chalmers Campbell notes that Joanna Herbert and Alice Chalmers were together for most of forty-five years, NLS Acc. 8695/117, ts. "My Mother." 
understanding, Joanna was descended from a victim of forced indenture. ${ }^{95}$ Esther Chalmers's autobiography is clear in stating that Joanna was the daughter of a mother born in slavery through the rape of her mother; Esther remembers Joanna Herbert's talk about the bitterness of memory. Esther Chalmers's archive makes space for Joanna Herbert's story. It preserves a text by Hannah Chalmers Campbell recalling that Joanna Herbert told the children that "The Freedom come when my mother was a little girl." 96 Hannah Campbell's text explains that Joanna Herbert was a keen reader of the Times and a churchgoer, and it provides precious evidence that Herbert told the children stories, including Anansi tales, which had passed from Africa through the diaspora. ${ }^{97}$

Around 1908, Herbert wished to return to Guyana and Alice Chalmers arranged her passage and a pension. The archive includes her letters to Alice, Hannah, and Alison Chalmers, including one which asks that she be remembered to

${ }^{95}$ For indenture to Guyana, see Monica Schuler, "Liberated Africans in Nineteenth-Century Guyana," in Brian L. Moore, B. W. Higman, Carl Campbell, and Patrick Bryan, eds., Slavery, Freedom, and Gender: The Dynamics of Caribbean Society (Kingston, Jamaica: University of the West Indies Press, 2003), 133-159.

${ }^{96} \mathrm{EBC}$ was proud that among her own ancestors was one who changed his life because of revulsion at slavery; Robert Stodart, her great-great-grandfather went to Tobago but left "he saw too much [of slavery] at first hand" and apprenticed instead to Swiss piano-maker Burkhart Tschudi; NLS Acc. 8695/85 regards; EBC autobiography, NLS Acc. 8695/1, p. 2.

${ }^{97}$ NLS Acc. 8695/117, ts. "My Mother." These may be unreliable memories, but Hannah Chalmers Campbell mentions "Brer Rabbit" and "Nanny" spider stories, as well as a song originally from Newfoundland which she remembers in a "creole" accent. 
the Bessires from this time. However, Herbert became unhappy in Georgetown and returned to Edinburgh and the Chalmers/Lorimer households until her death in the Edinburgh Women's Hospital in 1917. A draft copy of Joanna Herbert's will is tucked in a folder with Esther's earliest childhood writings. ${ }^{98}$ That will left a five pound bequest for the Scottish Episcopal Holy Cross Church then being built at Davidson's Mains; the building still stands. ${ }^{99}$

Esther Chalmers's archive includes precious photographs of Joanna Herbert in Edinburgh. But I said earlier that sometimes untold lives are in plain sight. Esther Chalmers and her sister Hannah Campbell take care to note Joanna Herbert's presence in paintings by their uncle, John Henry Lorimer: "The Mushroom Gatherers," "Lullaby," and "Bénédicité/Our Grandmother's Birthday." "100 In a variety of

${ }^{98}$ NLS Acc. $8695 / 122$.

${ }^{99}$ NLS Acc. 8695/110, "General Disposition and Settlement" document dated 1908, inside folder marked "Childhood." For Holy Cross, see http://www.holycrossedinburgh.org/?page_id=128 (accessed 5/18/2018). I am grateful to the Reverend Canon Dr. Douglas Kernahrens for conversation about Holy Cross's history and for showing me the church and some of its records. ${ }^{100}$ EBC, autobiography, NLS Acc. 8695/1, p. 2; NLS Acc. 8695/117, tss. "My Mother" and "The Kellie I Knew." Photocopies of the paintings are included in EBC's collection of images for use in "Out of the Green Box," NLS Acc.

8695/106. See also May C. Fenoulhet, "John Henry Lorimer, Scottish Artist, 1856-1936: A Critical Biography,” M. Litt. Thesis, University of Edinburgh, 1990, online at https://www.era.lib.ed.ac.uk/bitstream/handle/1842/18876/Fe noulhetMC_1990_v2redux.pdf?sequence $=2 \&$ is Allowed $=y$ (accessed 10/28/2017); EBC met with and assisted Fenoulhet 
ways, Esther Chalmers's archive resists turning Joanna Herbert's life into a "mammy story," in which the historical importance of a woman of color rests only in the fact that some white children once loved and depended on her. Esther Chalmers ensured that the visual evidence of Joanna Herbert's life in Scotland was documented, and she took care to inscribe Joanna Herbert's African lineage as far as she could: Herbert "had the high cheekbones, the dignified bearing of a Mende warrior." ${ }^{101}$ The Mende people are principally from Sierra Leone.

VI.

Christopher Fyfe, who died in 2008, was born in 1920. Although his family was Scottish, his life included time in Ontario, Oxford, Dusseldorf, Bristol, and Belfast, as well as Aberdeen, before he settled in Edinburgh in 1962 . He remained for many years and became deeply committed to the preservation of the Scottish past as an activist on behalf of the Old Town and the development of contemporary Scottish culture, notably as a supporter of the Traverse Theatre. ${ }^{102} \mathrm{He}$ participated as well in organizations addressing homelessness, slum housing, and the needs of young people. He left his papers dealing with these social issues and with historical

during her research (NLS Acc. 8695/45, EBC diary entry for 24 April 1980 and passim).

${ }^{101}$ EBC autobiography, NLS Acc. 8695/1, p. 2.

102 This and the following information are synthesized from: obituary of Christopher Fyfe, The Scotsman, 16 September 2008 , online at http://www.scotsman.com/news/obituaries/christopher-fyfe-11090880, accessed 10/28/2017; and John Hargreaves, "Christopher Fyfe," Guardian, Education section, 28 October 2008. 
preservation to the NLS, with prefatory texts to each file, "a narrative account by Christopher Fyfe of the background to the particular protest campaign, or the origins of an individual community association or action group" and directions that these "should be read straight through in order to obtain an overview of the circumstances in which the papers were accumulated."103 Like Esther Chalmers, Christopher Fyfe took no chances with this archival legacy.

Fyfe's larger legacy was his work as an important, innovative, and generous historian of Sierra Leone. He first went to Sierra Leone in 1950 as an (officially entirely unqualified) archivist; he rapidly retrieved, preserved, and organized an irreplaceable collection of documents. He went on to write a history of Sierra Leone which was shaped, in part, by his reading of Wittgenstein and James Joyce. Appointed to a post in African history at the University of Edinburgh in 1962, he went on to edit and write many more books of Sierra Leonean history, including a biography of James Africanus Horton, the first African student to graduate from Edinburgh. ${ }^{104} \mathrm{He}$ refused promotion to a professorship on the grounds that resources should go to creating posts for younger scholars. He served as editor of the Journal of African History and took on other official responsibilities, and he was remembered as well for his less official roles. "In the 1970s, when the African scene in Edinburgh was vibrant, the 'wee Fyfe' was a central figure. His bohemian parties in St Mary's

${ }^{103}$ Inventory to NLS Acc. 10699, "Papers of Christopher Fyfe relating to planning matters, community involvement and amenity groups in central Edinburgh, 1970-1992," https://www.nls.uk/catalogues/online/cnmi/inventories/acc10 669.pdf (accessed 10/28/2017).

${ }^{104}$ Christopher Fyfe, A History of Sierra Leone (Oxford: OUP, 1962); and Africanus Horton, 1835-1883: West African Scientist and Patriot (Oxford: OUP, 1972). 
Street were, as one colleague put it, "worthy of record by a latter-day Cockburn." "105 He did not marry but was close to his family, especially a nephew. Most profoundly, he was appreciated in Sierra Leone and Sierra Leoneans elsewhere, especially by Krio people. He was specially honored at a 1987 celebration of the bicentenary of Freetown. ${ }^{106}$ His role in modern Sierra Leonean history went beyond his publications.

Esther Chalmers may have contacted Christopher Fyfe directly during her research; she could have met him through Basil Davidson, the eminent Africanist with whom she corresponded about a history they shared with Robert Lee Wolff, the history of the Balkans. ${ }^{107}$ Their paths could have

105 Scotsman obituary, n. 92 above.

106 See, e.g., book review of Fyfe, History of Sierra Leone, Sierra Leone Studies, n.s. 17 (June 1963), reprinted at http://www.natinpasadvantage.com/Sierra_Leone_History/Re view_of_A_History_of_Sierra_Leone,_Christopher_Fyfe_par t1.html (accessed 10/28/2017), and http://www.thepatrioticvanguard.com/tribute-to-renownedhistorian-christopher-fyfe, accessed 10/28/2017; obituary by Mac Dixon-Fyle on H-Africa listserv, https://hnet.msu.edu/cgi-bin/logbrowse.pl?trx=vx\&list=hafrica\&month $=0808 \&$ week $=e \& m s g=$ MxqGciLpCHe3DuEP/ $\underline{\text { 87I8A\&user }=\& p w}=$ and James Walker, "reply," 2 September 2008, http://h-net.msu.edu/cgibin/logbrowse.pl?trx $=$ vx \&list=h-westafrica\&month $=0809 \&$ week $=a \& m s g=A h R C / 1 B x p h 416 v p Q 0 n$ JWWw\&user $=\& p w=$ (both accessed 10/28/2017).

${ }^{107}$ NLS Acc. 8695/3, is the ts. of an account of a journey in Dalmatia in 1931 in which EBC later discerned fascist codelanguage, and a letter from Davidson of 20 December 1981 returning this "Serbian memoir" notes that "Christopher" was in Gambia. 
crossed on the many shared terrains of Edinburgh and its history. No letters to or from Christopher Fyfe remain in Esther Chalmers's archive although he appears in her address books and diary; when he visited her in Anstruther in 1980, she wrote that the day was "not nearly long enough" but "lovely," as well as that he too took an interest in the Scottish Fisheries Museum. ${ }^{108}$ In any case, the NLS's acquisition records note that, after the death of Esther Chalmers in 1983, her papers came there "through the good offices of Christopher Fyfe."109

\section{VII.}

This essay has not been a biography of Esther Chalmers---nor of Lucie Dejardin, the many Lorimers and Chalmerses, the Bessire/Guilluame family, Robert Lee Wolff, Joanna Herbert, or Christopher Fyfe. It is not even a full biography of an archive; that archive contains more threads to be followed and more intertextual and inter-archival connections to explore. It certainly leaves unanswered questions. Some may be answered with further research; others will remain. At the least, this essay will increase the sometimes unexpected visibility of some names in searches of current and developing digital archives. Yet clearly Esther Chalmers created her archive, including some very long texts. Her care and control

108 NLS Acc. 8695/49 (c. 1978-80) and 50 (undated); NLS Acc. 8695/45, EBC diary for 1980, entry for 26 April. ${ }^{109}$ I am indebted to Alison Metcalfe of the NLS for finding and sharing this information with me in August 2017. It appears that EBC first approached the Edinburgh University Library about some of her materials (NLS Acc. 8695/45, entry for 7 December 1980 and 8695/46, entry for 15 January 1981); Christopher Fyfe's own papers are in both the NLS and the University Library. 
ensured that at her death it passed not to or only through family hands but through the care of a remarkable Scottish and international historian of Africa, a proponent of cultural innovation and advocate for the needs of the most vulnerable people of Edinburgh. Through Christopher Fyfe, Esther Chalmers's work came to the National Library of Scotland, a building ornamented by sculptures by her kinsman Hew Lorimer. But again: this is not a story of rebellion against or disavowal of family or place: Esther Chalmers and Hew Lorimer were on good terms and collaborated in family history. He provided many kindnesses during her later years. It can only be through Hew Lorimer's permission that John Henry Lorimer's portrait of David Chalmers hung, and still hangs, in Kellie Castle.

Esther Barbara Chalmers left an extraordinary and incomplete map of relations between Scottish and other histories. It demonstrates that such relations were not always extraordinary but could thickly knotted into visible daily lives for some. It suggests that radical questioning and decisive new commitments could flow from and alongside these inherited relations. Her work deserves to be continued by historians of many kinds making use of it. Her own Scottish international life is only one of those she brought to history.

It is a truism: Lives can be told in many ways.

The author would like to particularly thank James Fraser for his generosity and acute suggestions; Geoff Eley for endless empathetic support; and Peter Syme for his lively interest including a superb excursion to Kellie Castle and elsewhere in Fife. 